\title{
Use of Nonlinear Dynamic Motivational Strategies to Manage L2 Academic Entitlement and Psychological Reactance
}

\author{
Akbar Bahari \\ University of Qom \\ Correspondence concerning this article should be addressed to Akbar Bahari, University of Qom, \\ Ghadir Blvd., 3716146611, Qom, Qom, Iran.E-mail: bahariakbar2020@gmail.com
}

\begin{abstract}
Expanding the dynamicity and nonlinearity of L2 motivation introduced by Bahari (2019a) based on the complex dynamics systems theory has served as the theoretical framework to introduce and contextualize nonlinear dynamic motivational strategies (NDMSs). The present study used the NDMSs to manage L2 academic entitlement and psychological reactance as two obstructive factors in the L2 learning-teaching process. For conceptualization purposes, a mixed methods approach was conducted among teachers as well as learners to examine the effectiveness of proposed strategies as a pedagogical tool to manage and minimize these obstructive factors in academic contexts. The observed effectiveness of the NDMSs at managing and minimizing the analyzed obstructive factors along with replacing teacher-centered and test-oriented L2 classrooms with a learner-friendly motivating L2 classroom has significant pedagogical and theoretical implications. The major finding of the study following a rigorous methodological triangulation of the data that was collected confirms the effectiveness of the NDMSs as an L2 teaching strategy to cater to the diversity of individual differences for the purpose of improving teacher-learner interactions. Drawing on the results, it can be safely concluded that the NDMSs as the independent variable of the study showed significant impact on managing and minimizing academic entitlement and psychological reactance.
\end{abstract}

Keywords: academic entitlement (AE), psychological reactance (PR), nonlinear dynamic motivational strategies (NDMSs), complex dynamics systems theory (CDST)

\section{Introduction}

When a second language (L2) learner believes that his/her lack of achievement is the result of a teacher's decision, he/she feels entitled to the achievement (Major, 1994) and expresses oppositional behavior via anger mechanisms. Similarly, in situations where individual autonomy or freedom is restrained, oppositional behavior is the common behavior (Brehm, 1996) which leads to resistance, incivility, and dissent as different aspects of reactance. The same oppositional behavior occurs when nonlinear dynamic L2 motivational factors are restrained (Bahari, 2018). Given the obstructive nature of academic entitlement (AE) and psychological reactance $(\mathrm{PR})$ in the L2 teaching-learning context, the present study proposed the use of nonlinear dynamic motivational strategies (NDMSs) as a valid tool for managing and minimizing the obstructive influence of these factors in L2 teaching-learning.

\section{Literature Review}

Academic entitlement (AE) is a shift in values of education that undermines the face of education by offering achievement without any effort or skill (Morrow, 1994) or expressing anger over a low grade (Chowning \& Campbell 2009; Ciani, Summers, \& Easter, 2008; Greenberger, Lessard, Chen, \& Farruggia, 2008). AE can trigger failure in learning contexts as an obstructive factor in teacher-learner relationships. While searching for the origins of AE among academically entitled students, several studies (Campbell, Bonacci, Shelton, Exline, \& Bushman, 2004; Foster, Campbell, \& Twenge, 2003; Hoover 2007; Lombardi, 2007; Twenge 2006) have addressed learner-related concepts (e.g. motivation, narcissism, and (inflated) self-esteem). Under reactance theory (RT), displaying oppositional behavior is a common response in human behavior (Brehm, 1996) however, most of the 
Figure 1

L2 Teaching-Learning Obstructive Factors

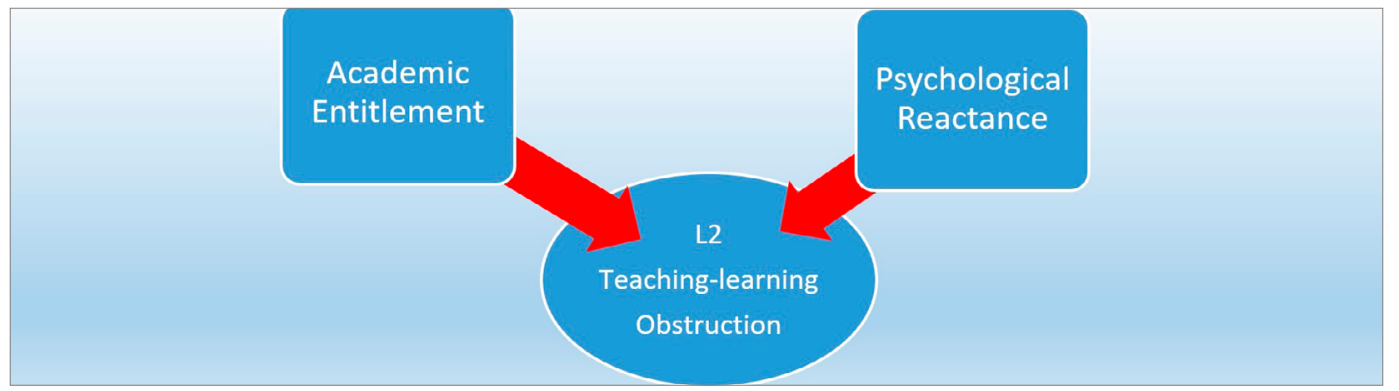

studies on learning have applied psychological reactance apropos of the learner under labels such as uncivil behavior (Achacoso, 2002; Chowning \& Campbell, 2009; Ciani, et al., 2008; Greenberger, et al., 2008; Kopp \& Finney, 2013; Lippmann, Bulanda, \& Wagenaar, 2009; Nutt, 2013) or an uncivil classroom (Bjorklund \& Rehling, 2009; Clark \& Springer, 2007; Cortina, Magley, Williams, \& Langhout, 2001; Feldmann, 2001). However, this is mostly done without considering the role for the teacher in stirring up uncivil behavior, which is clearly against the basic principle of RT. The basic principle of PR is that oppositional behavior is a common response in human behavior (Brehm, 1996) that is applied to situations where individual autonomy or freedom is restrained by some mechanisms. Therefore, when learner autonomy is restrained, psychological reactance on the part of the learner is a common behavior. The L2 teaching-learning context, when it is the same as other learning contexts, might be the environment where such oppositional behaviors originate. The present study suggests the use of the NDMSs to avoid such an obstructive environment. The question then arises, "Do NDMSs have the potential to manage AE and PR in L2 teaching-learning contexts?" Imagine a teacher taking demotivating measures instead of catering to the motivational needs of L2 learners, or restraining learner autonomy via test-score manipulation. Now the next question arises, "Can this teacher manage reactance, prevent incivility, minimize resistance, and manage dissent while taking anti-motivational measures in L2 teaching-learning contexts?" Restricting learners' pedagogical preferences by ignoring their motivational factors is an example of restricting freedom/autonomy in L2 teaching-learning contexts, which increases the chances of reactance (Jost, Banaji, \& Nosek, 2004). Accordingly, adopting test-oriented instruction, threatening policies, reactance-inducing statements and feedback (Bahari, 2019a) obstruct the learning process to a large extent. Given the fact that restrictive measures are met with backlash (Laurin, Kay, Proudfoot, \& Fitzsimons, 2013) they need to be avoided in keeping with the internalized concepts of self and identity (Ushioda \& Dörnyei, 2017) in L2 motivation.

Based on the reported ineffectiveness of linear patterns in explaining and predicting the relationships observed in SLA data, (Bahari, 2019a, 2020a; de Bot \& Larsen Freeman, 2011; de Bot, Lowie, \& Verspoor, 2007; Dörnyei, 2014; Fusella, 2013; Hiver, 2015; Kikuchi, 2015; Larsen-Freeman \& Cameron, 2008; MacIntyre \& Legatto, 2011), the present study tried to incorporate the principles of complex dynamics systems theory (CDST) as a solution to this deficiency. To this end, the NDMSs arranged based on the CDST were used to manage and minimize $\mathrm{AE}$ and PR. The CDST considers the components of the system (either with two variables or with innumerable variables) in a global way and confirms that a nonlinear process is at work within the system and in interactions between every internal and external stimuli (Henry, Dörnyei, \& Davydenko, 2015; Jiang \& Dewaele, 2015).

Given the complete interconnectedness of variables in the language learning context, the proposed NDMSs could potentially influence many other variables in the L2 learning context (e.g. self-efficacy, anxiety, etc.); however, in the present study they are expected to be applied to manage and minimize AE and PR. In other words, given the dynamic trajectory of interacting variables in learning contexts and the ever-changing interactions between them, the study focused on examining the effectiveness of the NDMSs for managing and minimizing two variables out of innumerable dynamic variables present in the language learning context. Therefore, it is impossible to adopt all of the relevant features of a complex system such as the L2 learning system in a single study with respect to feasibility and other limitations. This aspect was rarely approached in previous studies, which approached L2 motivation apropos of strategies (Griffiths, 2013; Oxford, 2017; Quoidbach, Mikolajczak, \& Gross, 2015; Schunk \& Zimmerman, 2012) or as a static factor (Moskovsky, Racheva, Assulaimani, \& Harkins, 2016) or a learner-context interaction subject (Thompson \& Erdil-Moody, 2016) or introducing its influential factors (Lyubomirsky \& Layous, 2013; Rusk \& Waters, 2015; Sheldon, Boehm, \& Lyubomirsky, 2013). 
Drawing on CDST and the reported effectiveness of the NDMSs at attenuating the frequency of resorting to oppositional behavior on the part of the learners (Bahari, 2019b), the NDMSs were adopted as a multifaceted pedagogical tool to measure the rate of oppositional behavior among the participants in keeping with the psycho-socio-cultural aspects of L2 learner motivation (Bahari, 2018). To this end, the dynamic psychological, social, and cultural features of L2 motivation were embedded in statements reflecting a dynamically oriented taxonomic structure (Hiver \& Al-Hoorie, 2016) in keeping with complex systems (de Bot, Lowie, \& Verspoor 2007; Dörnyei, MacIntyre, \& Henry, 2015; Dörnyei, Ibrahim, \& Muir, 2016; Hiver \& Al-Hoorie, 2016; Larsen-Freeman, 2015b; Larsen-Freeman \& Cameron, 2008; Serafini, 2017; Thompson, 2017). With the constant changes and adaptation in L2 motivation under CDST, the proposed strategies are meant to intervene (to minimize and manage AE and PR) in interactional synchrony (i.e. the active interacting process) via creative communicative behavior. The main point here is the applicability of CDST to L2 motivation in terms of meeting the nonlinearity and dynamicity of L2 motivation at individual levels (Bahari, 2019a, 2020a) and not its applicability in terms of cognitive processing where information processing is considered a linear process. This is the point where it renders CDST inapplicable.

\section{Description of the Study}

The study was conducted to utilize the motivational surges at the individual level (Bahari, 2019b) and unlock the potential behind their nonlinearity and heterogeneity via the NDMSs. The proposed strategies are intended to integrate all of the components of the motivational superstructure from the directed motivational currents described as goal-oriented surges to other intense motivational experiences (Dörnyei, Henry, \& Muir, 2016) concerning nonlinear-dynamic L2 motivation. This process starts at the individual level by identifying the motivational factors in members of the learning group and moves onto the group level where identified motivational factors are examined for compatibility. Following that they are nonlinearly integrated and dynamically adopted by the teacher. The NDMSs are applied at three stages: the pre-motivational stage, the motivational stage, and the post-motivational stage. The first stage consists of steps starting with potential motivation diagnosis and ending with nonlinear integration. Drawing on nonlinearity and dynamicity, even the proposed hierarchy allows a dynamic order, which means there is no need to complete all the steps in a linear process and the order can change dynamically and nonlinearly based on what motivates the individual learner at that moment, without trying to impose what motivates one learner compared to another or the whole learner group. To diagnose the motivational disposition of L2 learners, the majority of studies suggest a focus on learners' Motivational Self System (Csizer \& Lukacs, 2010; Dörnyei, 2009, 2010; Lamb, 2012; Thompson \& ErdilMoody, 2016) or its variations such as intrinsic or extrinsic motivation, etc. (Csiz'er \& Magid, 2014; Dörnyei \& Chan, 2013; You, Dörnyei, \& Csiz'er, 2016). However, the missing point in these studies is the lack of addressing the nonlinearity and dynamicity of L2 motivation via a comprehensive approach. To bridge this gap, we need to identify tedious and boring experiences from the past as well as the attractive and enjoyable experiences of the learners (Dörnyei, Ibrahim, \& Muir, 2015), apropos of dynamics of motivation (Waninge, Dörnyei, \& de Bot, 2014) at the nonlinear dynamic individual level instead of the group level (Bahari, 2019a). The present study hopes to approach this problem through the rigorous integration of the elements of psychological reactance (Brehm, 1966; Brehm \& Brehm, 1981) into the NDMSs via continual cognitive-motivational functioning (Dörnyei, 2010; Larsen-Freeman, 2015a) to manage and minimize oppositional behaviors on the part of the learners. To this end, it is critical to make sure that previously identified motivational factors are dynamically and nonlinearly compatible in terms of motivational intensity, motivational imagery, and motivational behavior (You \& Chan, 2015) with respect to gender differences (Henry \& Cliffordson, 2013; You, Dörnyei, \& Csiz'er, 2016) and can act together to unlock the potential behind nonlinear dynamic motivation. The dynamic compatibility of the NDMSs should not be confused with 'cohesive groups' which has been used in the literature. While the former is an attempt to find out the rate of compatibility among motivational strategies in order to sort and categorize them under multiple dynamic motivational strategies, the latter is an attempt to group the learners under a single group which is labeled as a 'cohesive group' regardless of the nonlinear and dynamic nature of the motivational factor in each and every member of the learning group.

Given that restricting behavioral options can lead to a preference for the restricted action (Laurin et al., 2013) and that ignoring motivation or demotivation can negatively influence L2 teaching-learning (Chang, 2010; Kikuchi, 2009; Kim, 2009; Oxford, 2017; Quoidbach, Mikolajczak, \& Gross, 2015; Trang \& Baldauf, 2007), the present study explored the connections of these L2-obstructive factors versus L2-facilitating NDMSs to find a solution to change the opposition-inducing teaching-learning context into a motivation-inducing context. 
Figure 2

NDMSs to Manage Psychological Reactance and Academic Entitlement

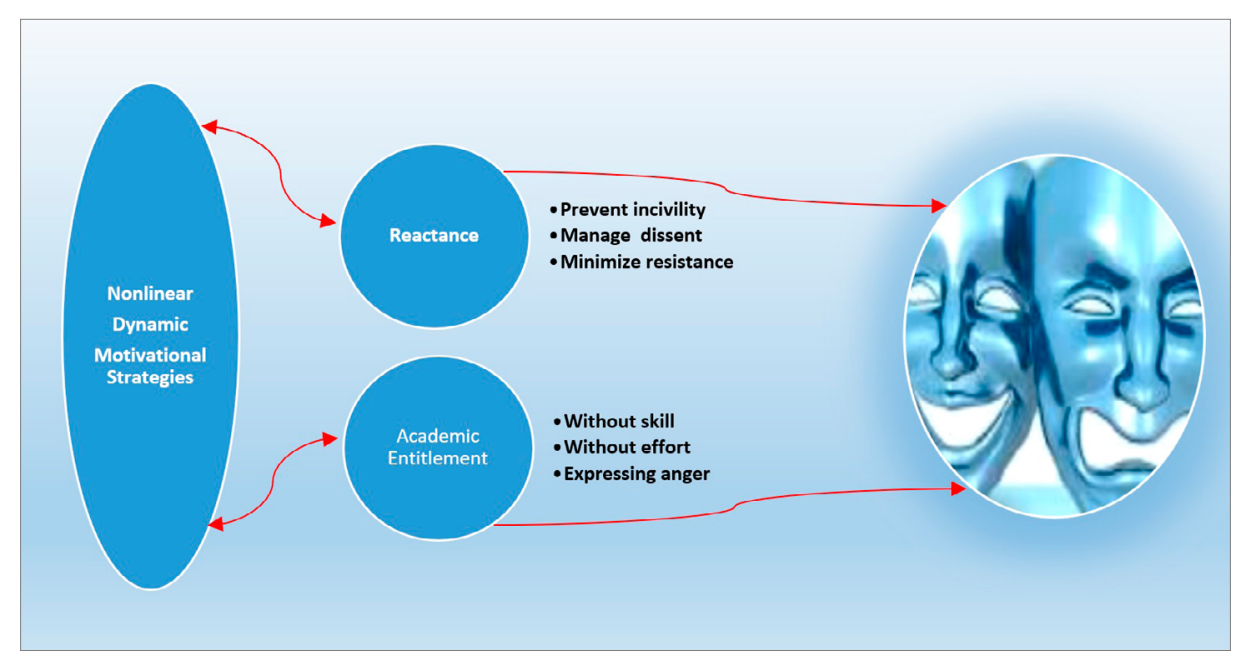

To this end, the NDMSs were proposed as a facilitator to deal with the challenge of AE and PR in L2 teachinglearning contexts. A mixed methods approach was applied to examine the relationship between the NDMSs and L2 learner-teacher attitudes towards incivility prevention, resistance minimizing, and dissent management with a focus on three aspects: learner-teacher anxiety, frustration, and self-doubt. To familiarize participants with the NDMSs proposed by (Bahari, 2018) and its application in L2 teaching-learning contexts, several workshops (5 sessions for professors' group and 10 sessions for students' group) were conducted before administering questionnaires to provide practical experience for the participants before responding to the NDMSs-oriented questionnaires. Different strands of data collection were used to answer the following questions:

RQ1: How effective are NDMSs as a valid tool for managing and minimizing PR in L2 teaching-learning contexts at three levels of incivility prevention, dissent management, and resistance minimizing?

RQ2: How effective are NDMSs as a valid tool for managing and minimizing AE in L2 teaching-learning contexts?

RQ3: What patterns can be observed between teacher-learner responses about the effectiveness of NDMSs for managing AE and PR in L2 teaching-learning contexts?

RQ4: What relationship can be seen between teachers' and students' responses about the effectiveness of NDMSs (arranged on psycho-socio-cultural aspects of L2 motivation) as a tool to minimize/ manage $\mathrm{AE}$ and $\mathrm{PR}$ ?

\section{Setting and Participants}

\section{Method}

147 participants (36 professors in English Language Teaching Methodology and 111 M.A. students in ELT Methodology) were drawn from three branches of Azad University in Tehran, Iran. To facilitate QUAL-QUAN analysis, the participants were divided into two groups: professors (female $=33 \%$ and male $=67 \%$ ) and students (male $=41 \%$ and female $=59 \%$ ). Professors' ages ranged 32-55 and Students' ages ranged 25-42. Permission to participate in the research was obtained from the participants. The size of the population made it impossible to use random sampling for the purpose of generalizability. The study adopted intact group design to sample the participants and conduct the study.

\section{Data Sources}

The required data in response to the first three research questions were gathered by administering author-made questionnaires in English to the L2 teachers and learners (see Appendices A, B). Using the same statements to teacher-learner participants to elicit their attitudes on the effectiveness of the NDMSs on AE and PR 
management, the questionnaires were distributed among teachers as well as learners to collect their opinions. For the fourth research question an author-made semi-structured interview (see Appendix C) was rigorously prepared and administered among $50 \%$ of the participants (face-to-face/online).

\section{NDMSs - PR Questionnaire}

The NDMSs - PR Questionnaire was used to collect the required data in response to the first research question to measure the oppositional behavior. An author-developed survey with 45 items was used to examine the effectiveness of the proposed strategies at three levels of incivility prevention, resistance minimizing, and dissent management from three perspectives: frustration, self-doubt, and learner-teacher anxiety (see Appendix A). The items are rated along a 6 -step Likert continuum (e.g., $1=$ strongly agree to $6=$ strongly disagree). This was done in keeping with the studies (e.g. Chomeya, 2010) reporting higher discrimination and reliability values of the Likert's 6-point scale versus the Likert's 5-point scale. The questionnaire took approximately $40-45$ minutes to complete. Subjects were asked to respond to the items and they were encouraged to ask for explanation if they did not understand any of the items (face-to-face/online). The first fifteen items on the questionnaire assess learner attitudes towards incivility prevention. These are termed incivility prevention $(a=.68)$, the belief that learner incivility can be prevented by adopting some strategies with respect to frustration, self-doubt, and learner-teacher anxiety (e.g., "I think friendship strategy can prevent learner incivility and reduce learnerteacher anxiety). The second fifteen items on the questionnaire assess learners' attitudes towards resistance minimizing. These are termed resistance minimizing $(a=.77)$, the belief that resistance can be minimized by adopting some strategies with respect to frustration, self-doubt, and learner-teacher anxiety (e.g. "I feel less resistance and frustration when a controversial subject is delivered unbiasedly"). The third fifteen items on the questionnaire assess learners' attitudes towards dissent management. These are termed dissent management $(a=.70)$, the belief that one can manage dissent by adopting some strategies with respect to frustration, selfdoubt, and learner-teacher anxiety (e.g. "I believe that meeting students' dynamic motivational factors by the teacher can reduce the level of dissent and create a friendly environment with less anxiety and self-doubt"). The internal consistency of the 45 subscales measured in line with Wigfield and Guthrie (1995; Table 1) ranged from .68 to .77 at three levels of resistance minimizing, incivility prevention, and dissent management.

Table 1

Reliabilities of the NDMSs - Psychological Reactance Scale

\begin{tabular}{lcc}
\hline \multicolumn{1}{c}{ Subscales } & N of Items & Reliability \\
\hline Incivility Prevention & 15 & .68 \\
Resistance Minimizing & 15 & .77 \\
Dissent Management & 15 & .70 \\
\hline
\end{tabular}

\section{NDMSs - AE Questionnaire}

To collect the required data for the second research question, a researcher-made questionnaire with 16 items was prepared and distributed among learners and teachers (see Appendix B) to elicit their opinions concerning L2 AE management via the NDMSs. The author believes that teachers and learners have a mutual role for the creation and rise of the obstructive factors within the L2 teaching environment; therefore we need to collect their opinions on the same statements to avoid making a unidirectional decision. The internal consistency of the items that was measured in line with Wigfield and Guthrie (1995) ranged between .70 and .77.

\section{Interview to collect data on the effectiveness of NDMSs for managing and minimizing AE and PR}

To answer the fourth research question, an interview was administered among teachers as well as learners to find out what relationships can be observed between teachers' and learners' responses about the effectiveness of the NDMSs as a tool for minimizing/managing AE and PR (see Appendix C). NDMSs-AE and PR Self-Interview is a 5-part survey (see Appendix C) developed by the author to examine the efficiency of the NDMSs at three levels of preventing, minimizing, and managing obstructive factors. The first part elicits the interviewees' (i.e. teacher/learner) personal experiences (e.g., Have you experienced/witnessed psychological reactance and academic entitlement in terms of incivility, resistance, and dissent?). The elicited responses were interpreted 
and coded as $1=$ positive experience, $2=$ negative experience, $3=$ no experience, which were termed experience $(a=.74)$. The second part elicits the interviewees' attitudes concerning the effectiveness of the NDMSs on psychological reactance and academic entitlement with regard to previous experiences by asking questions (e.g., How influential are 'nonlinear dynamic motivation-oriented strategies' in L2 teaching-learning by telling about your own experiences?). The elicited responses were interpreted and coded as $1=$ influential, $2=$ uninfluential, $3=$ undecided. The third part elicits the interviewees' responses regarding the need for psychological reactance and academic entitlement self-management in L2 teaching-learning by asking questions (e.g., How necessary is psychological reactance management in L2 teaching-learning?). The elicited responses were interpreted and coded as $1=$ necessary, $2=$ not necessary, and $3=$ undecided. These are termed need $(a=.72)$. The final construct elicits responses concerning the effectiveness of the NDMSs that can facilitate psychological reactance and academic entitlement self-management in L2 teaching-learning (e.g. eliminating test-oriented classes, providing novel activities, and improving learner achievement) by asking question (e.g., Do you think that eliminating testoriented classes can facilitate preventing incivility, minimizing resistance, and managing dissent in face-toface/online L2 teaching-learning?). The elicited responses were interpreted and coded as $1=$ Yes, $2=$ No, and $3=$ Undecided. To determine the internal consistency, the subscales ( $\mathrm{LL}^{1}, \mathrm{LL}^{2}$, and $\mathrm{LSL}$ ) were measured in line with Wigfield and Guthrie (1997) alphas and the results ranged from .71 to .75 (Table 2).

Table 2

Reliabilities for the NDM-oriented reactance management interview Subscales

\begin{tabular}{lcc}
\hline \multicolumn{1}{c}{ Subscale } & N of Items & Reliability \\
\hline Experience & 2 & .74 \\
Effectiveness & 3 & .71 \\
Need & 2 & .72 \\
Strategy & 3 & .75 \\
\hline
\end{tabular}

\section{Data Analysis}

Thematic analysis of QUAL-QUAN data was conducted via mixing the data for the purpose of meta-inferences (Figure 3) in line with (Tashakkori \& Teddlie, 2003). To ensure the correctness of the results, an iterative analysis was done prior to the selection of QUAL-QUAN analyses. Quantitative analyses were used to examine the effectiveness of the NDMSs for managing and minimizing AE and PR. Given the unpaired and categorical nature of the collected data, to test the effectiveness of the NDMSs for managing or minimizing AE and PR, the Pearson Chi Square Test was used.

Figure 3

Visual Representation of the Study Design

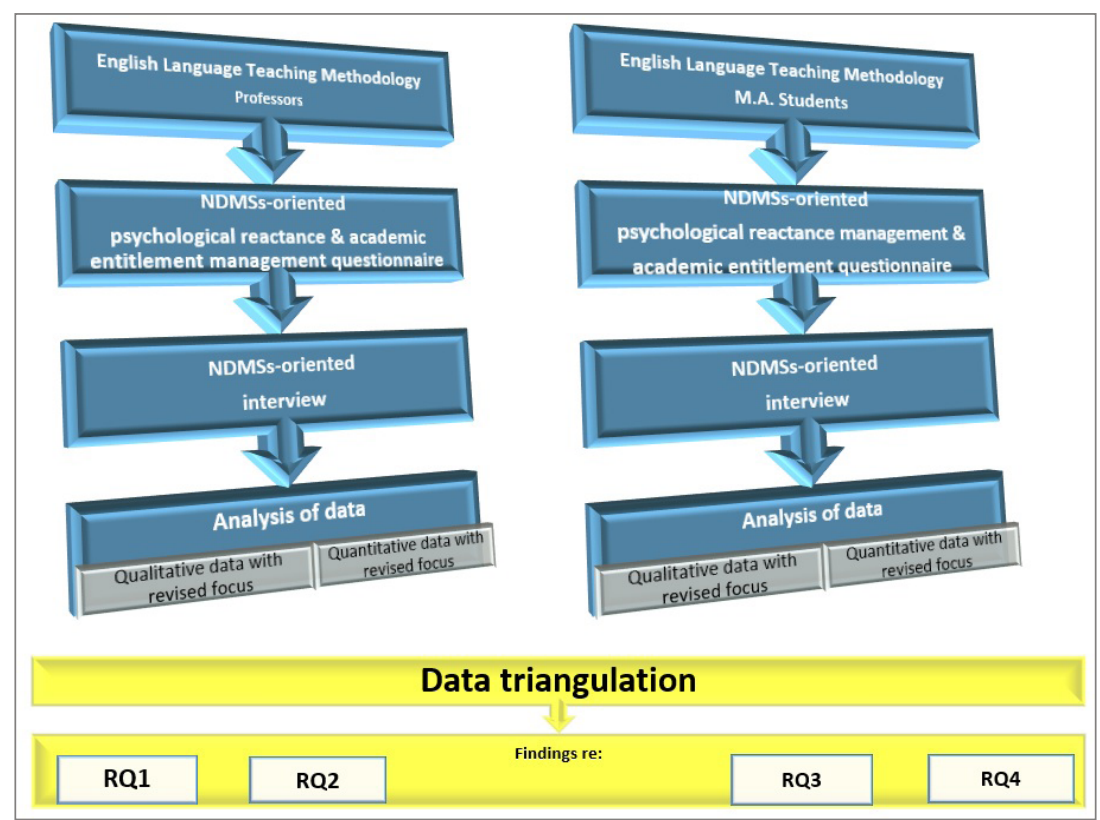


The transcribed interviews were scrutinized for codable NDMSs-oriented statements. In keeping with Urdan and Mestas (2006), the presence/absence of references (explicit/implicit) to obstructive factors in elicited responses was determined as the criterion for data coding. Sorting and categorizing elicited data in keeping with Saldaña (2013) provided a picture of the orientation of the collected responses following the use of subcoding techniques and preparing a list of codes (see Appendix C). To resolve the discrepancies and ensure inter-rater reliability, three expert EFL researchers were invited and the results of the analysis confirmed the inter-rater agreement at $78 \%$ per interview on average.

\section{Results}

The results of analyzing participants' responses to the NDMSs-PR questionnaire are displayed at three levels of civility prevention, resistance minimizing, and dissent management. The results showed that the majority of the participants (100\% of students and $48 \%$ of professors) held a positive view about the effectiveness of the NDMSs for preventing, minimizing, and managing psychological reactance. Drawing on the obtained results, the study confirms the effectiveness of the NDMSs and suggests that future studies should delve into the potential behind the NDMSs by contextualizing it in other contexts. The mean of the observed standard deviations $\mathrm{M}=1.185$ shows (see Table 3) that there were no polarized responses (except for negative responses elicited from male professors) and the majority of the participants (51.7\%) strongly believe in the effectiveness of the NDMSs.

Table 3

Descriptive Statistics on NDMSs \& PR (Incivility Prevention)

\begin{tabular}{llcccc}
\hline \multicolumn{5}{c}{ NDMSs \& PR (Incivility Prevention) } & \\
\hline & Frequency & Percent & Valid Percent & Cumulative Percent \\
\hline Valid & strongly agree & 76 & 51.7 & 51.7 & 51.7 \\
& agree & 40 & 27.2 & 27.2 & 78.9 \\
& slightly agree & 11 & 7.5 & 7.5 & 86.4 \\
& slightly disagree & 12 & 8.2 & 8.2 & 94.6 \\
& disagree & 8 & 5.4 & 5.4 & 100.0 \\
& Total & $\mathbf{1 4 7}$ & $\mathbf{1 0 0 . 0}$ & $\mathbf{1 0 0 . 0}$ & \\
\hline
\end{tabular}

The observed frequencies concerning the participants' responses on the effectiveness of the NDMSs are displayed in the frequency table of the Chi-Square Test (see Table 4). The majority of the respondents (127 out of 147) held a positive opinion concerning the effectiveness of the proposed strategies to prevent incivility in L2 learning environments. The upper range of the Table (i.e. 6) shows no cases of negative opinions, while the expected number was 42.0 . This can be interpreted as the lack of a strong negative opinion on the part of the participants (particularly teachers who mostly expressed negative opinions). In other words, there might be some other reasons for opting disagree/slightly disagree beyond the effectiveness of the proposed strategies (e.g. they might think that other factors should be included, etc.).

Table 4

Chi-Square Test for NDMSs \& PR (Incivility Prevention)

\begin{tabular}{llccc}
\hline \multicolumn{5}{c}{ Frequencies } \\
\hline & \multicolumn{5}{c}{ NDMSs \& PR (Incivility Prevention) } \\
\cline { 2 - 5 } & & Cbserved N & Expected N & Residual \\
\hline 1 & strongly agree & 76 & 7.0 & 69.0 \\
2 & agree & 40 & 14.0 & 26.0 \\
3 & slightly agree & 11 & 21.0 & -10.0 \\
4 & slightly disagree & 12 & 28.0 & -16.0 \\
5 & disagree & 8 & 35.0 & -27.0 \\
6 & Strongly disagree & 0 & 42.0 & -42.0 \\
Total & & $\mathbf{1 4 7}$ & & \\
\hline
\end{tabular}


The test statistics (see Table 5) compare the expected and observed values. In this case, the discrepancy was very large and statistically significant. (Asymp. Sig. $=.000)$. The results of the Chi-Square test concerning the observed frequency of responses between participants (i.e. teachers and learners) and a significant interaction was found $\mathrm{X}^{2}(5)=\mathrm{p}<.05$. Therefore, the majority of students as well as the majority of female teachers (except for $62 \%$ of male teachers) had a positive opinion about the effectiveness of the NDMSs as a valid tool to prevent incivility among L2 learners.

Table 5

Chi-Square Test Statistics (Incivility Prevention)

\begin{tabular}{|c|c|c|c|}
\hline \multicolumn{4}{|c|}{ Test Statistics } \\
\hline & & & NDMSs \& PR (Incivility Prevention) \\
\hline Chi-Square & & & $805.162^{\mathrm{a}}$ \\
\hline df & & & 5 \\
\hline Asymp. Sig. & & & .000 \\
\hline \multirow{3}{*}{ Monte Carlo Sig. } & Sig. & & $.000^{\mathrm{b}}$ \\
\hline & \multirow{2}{*}{ 99\% Confidence Interval } & Lower Bound & .000 \\
\hline & & Upper Bound & .000 \\
\hline
\end{tabular}

In response to part of the first research question, a Chi-Square test was run to provide a picture of the observed frequencies concerning the participants' responses regarding the effectiveness of the NDMSs for the dissent management variable (see Table 4). The majority of the respondents (126 out of 147) held a positive opinion concerning the effectiveness of the proposed strategies for dissent management in L2 learning environments. A look at the upper range of the Table (i.e. 6) reveals that the observed negative cases was zero, while the expected number was 42.0. This reflects the lack of a strong negative opinion on the part of the participants (even male teachers who mostly expressed negative opinions but did not select the strongly negative choice).

Table 6

Chi-Square Test (Dissent Management)

\begin{tabular}{llccc}
\hline \multicolumn{5}{c}{ Frequencies } \\
\hline & \multicolumn{5}{c}{ NDMSs \& PR (Dissent Management) } & & \\
\cline { 2 - 5 } & & Observed N & Expected N & Residual \\
\hline 1 & strongly agree & 89 & 7.0 & 82.0 \\
2 & agree & 31 & 14.0 & 17.0 \\
3 & slightly agree & 6 & 21.0 & -15.0 \\
4 & slightly disagree & 12 & 28.0 & -16.0 \\
5 & disagree & 9 & 35.0 & -26.0 \\
6 & & 0 & 42.0 & -42.0 \\
\multicolumn{1}{l}{ Total } & $\mathbf{1 4 7}$ & & \\
\hline
\end{tabular}

The Chi-Square test statistics (see Table 7) compared the expected and observed values. In this case the discrepancy was very large and statistically significant. (Asymp. Sig. $=.000$ ). The Chi-Square calculated the frequency of responses between participants (i.e. teachers and learners), and a significant interaction was found $\mathrm{X}^{2}(5)=\mathrm{p}<.05$. Therefore, the majority of students as well as the majority of female teacher (except for male teachers) had positive opinions on the effectiveness of the NDMSs as a valid tool to manage dissent among L2 learners. 
Table 7

Chi-Square Test Statistics

\begin{tabular}{|c|c|c|c|}
\hline \multicolumn{4}{|c|}{ Test Statistics } \\
\hline & & & NDMSs \& PR (Dissent Management) \\
\hline Chi-Square & & & $1062.386^{\mathrm{a}}$ \\
\hline $\mathrm{df}$ & & & 5 \\
\hline Asymp. Sig. & & & .000 \\
\hline \multirow{3}{*}{ Monte Carlo Sig. } & Sig. & & $.000^{\mathrm{b}}$ \\
\hline & \multirow{2}{*}{ 99\% Confidence Interval } & Lower Bound & .000 \\
\hline & & Upper Bound & .000 \\
\hline
\end{tabular}

In response to the other part of the first research question, a Chi-Square Test was run (see Table 8). The goal was to evaluate whether the NDMSs are effective tools to minimize resistance. Based on the results, 63 out of 147 strongly agreed, 52 out of 147 agreed, and 11 out of 147 participants held a positive view on the effectiveness of the proposed strategies for minimizing resistance. As with the previous analyses of the PR levels (incivility prevention and dissent management), we observe that there was no strongly disagree choice observed in the elicited responses from the participants, which reflects their tendency towards the positive opinions.

Table 8

Chi-Square Test Frequencies (Resistance Minimizing)

\begin{tabular}{llccc}
\hline \multicolumn{5}{c}{ Frequencies } \\
\hline & \multicolumn{5}{c}{ NDMSs \& PR (Resistance Minimizing) } \\
\cline { 2 - 5 } & \multicolumn{5}{c}{ Category } & Observed N & Expected N & Residual \\
\hline 1 & strongly agree & 63 & 7.0 & 56.0 \\
2 & agree & 52 & 14.0 & 38.0 \\
3 & slightly agree & 11 & 21.0 & -10.0 \\
4 & slightly disagree & 12 & 28.0 & -16.0 \\
5 & disagree & 9 & 35.0 & -26.0 \\
6 & & 0 & 42.0 & -42.0 \\
Total & $\mathbf{1 4 7}$ & &
\end{tabular}

Table 8 shows the Chi-Square analysis that calculated the frequency of responses between participants (i.e. teachers and learners), and a significant interaction was found $\mathrm{X}^{2}(5)=\mathrm{p}<.001$. From the test statistics output table we can observe the Chi Squared statistic, $x 2=626.362$, degrees of freedom 5, corresponding to $\mathrm{p}<0.001$. Therefore, we can conclude with $99.9 \%$ confidence that there is very strong evidence of the association between adopting the NDMSs and minimizing resistance.

Table 9

Test Statistics

\begin{tabular}{|c|c|c|c|}
\hline \multicolumn{4}{|c|}{ Test Statistics } \\
\hline & & & NDMSs \& PR (Resistance Minimizing) \\
\hline Chi-Square & & & $626.362^{\mathrm{a}}$ \\
\hline df & & & 5 \\
\hline Asymp. Sig. & & & .000 \\
\hline \multirow{3}{*}{ Monte Carlo Sig. } & Sig. & & $.000^{\mathrm{b}}$ \\
\hline & \multirow{2}{*}{ 99\% Confidence Interval } & Lower Bound & .000 \\
\hline & & Upper Bound & .000 \\
\hline
\end{tabular}

The results of the above analyses confirm the effectiveness of the NDMSs for managing and minimizing PR at three forms of incivility, resistance, and dissent. Accordingly, both groups believed that the NDMSs have the potential to manage these obstructive factors in classroom contexts. The negative responses by $52 \%$ of the professors ( $42 \%$ of the female professors and $62 \%$ of the male professors) can be interpreted as their traditionallyestablished preferences for teacher-centered L2 teaching. This also reflects their orientation towards monologic 
instruction instead of a dialogic one, which ends up in a non-learner-friendly context with a high risk of causing $\mathrm{AE}$ and PR in L2 teaching-learning.

Running a Chi-square test in response to the second research question revealed the following results. The results of the Chi-Square test frequencies showed a significant number of responses were positive (ranging from strongly agree $=79$, agree $=51$, to slightly agree $=8$ ), with only 9 out of 147 negative opinions on the effectiveness of the NDMSs for managing and minimizing AE among L2 learners (Table 10).

Table 10

Chi-Square Test Frequencies

\begin{tabular}{llccc}
\hline \multicolumn{5}{c}{ Frequencies } \\
\hline & \multicolumn{5}{c}{ NDMSs \& Academic Entitlement } & & \\
\cline { 2 - 5 } & & Observed N & Expected N & Residual \\
\hline 1 & strongly agree & 79 & 7.0 & 72.0 \\
2 & agree & 51 & 14.0 & 37.0 \\
3 & slightly agree & 8 & 21.0 & -13.0 \\
4 & slightly disagree & 6 & 28.0 & -22.0 \\
5 & disagree & 3 & 35.0 & -32.0 \\
6 & & 0 & 42.0 & -42.0 \\
Total & $\mathbf{1 4 7}$ & & \\
\hline
\end{tabular}

The results of the Chi-Square Test (see Table 11) calculating the frequency of responses elicited from the participants (i.e. teachers and learners), showed a significant interaction between the NDMSs and AE $\mathrm{X}^{2}(5)=$ $\mathrm{p}<.001$. We can observe from the test statistics output table the Chi Squared statistic, $x 2=934.948$, degrees of freedom 5 , corresponding to $\mathrm{p}<0.001$. Therefore, based on the obtained results the present study confirms with $99.9 \%$ confidence that there is very strong evidence of the association between adopting the NDMSs and minimizing resistance among the L2 learners in the study.

Table 11

Chi-Square Test Statistics on NDMSs \& Academic Entitlement

\begin{tabular}{|c|c|c|c|}
\hline \multicolumn{4}{|c|}{ Test Statistics } \\
\hline & & & NDMSs \& Academic Entitlement \\
\hline Chi-Square & & & $934.948^{\mathrm{a}}$ \\
\hline $\mathrm{df}$ & & & 5 \\
\hline Asymp. Sig. & & & .000 \\
\hline \multirow{3}{*}{ Monte Carlo Sig. } & Sig. & & $.000^{\mathrm{b}}$ \\
\hline & \multirow{2}{*}{ 99\% Confidence Interval } & Lower Bound & .000 \\
\hline & & Upper Bound & .000 \\
\hline
\end{tabular}

In an answer to the third question, searching for patterns between teacher-learner responses about the effectiveness of the NDMSs for managing AE and PR, the results of the analyses revealed that there was a statistically significant correlation between different forms of psychological reactance (incivility prevention, resistance minimizing, and dissent management) with Sig. (2-tailed) $<0.05$. A closer look at our results reveals that the strongest correlation was between incivility prevention and resistance management, where $r=.936$. It was based on $\mathrm{N}=147$ students and teachers and its 2-tailed significance, $\mathrm{p}=0.000$, which means there is a 0.000 probability of finding this sample correlation or a larger one if the actual population correlation is zero. The results of the analysis also revealed that there was no correlation between PR and AE in the elicited data. Its strongest correlation was between the NDMSs \& AE and incivility prevention where the correlation was .039 but $\mathrm{p}=.635$ which was not statistically different from zero. That is there was a .039 chance of finding it if the population correlation was zero. 
Table 12

Correlations

\begin{tabular}{|c|c|c|c|c|c|}
\hline \multicolumn{6}{|c|}{ Correlations } \\
\hline & & $\begin{array}{c}\text { NDMSs \& PR } \\
\text { (Incivility } \\
\text { Prevention) }\end{array}$ & $\begin{array}{c}\text { NDMSs \& PR } \\
\text { (Resistance } \\
\text { Minimizing) }\end{array}$ & $\begin{array}{l}\text { NDMSs \& PR } \\
\text { (Dissent } \\
\text { Management) }\end{array}$ & NDMSs \& AE \\
\hline \multirow{3}{*}{$\begin{array}{l}\text { NDMSs \& PR } \\
\text { (Incivility Prevention) }\end{array}$} & Pearson Correlation & 1 & .936 & .874 & .039 \\
\hline & Sig. (2-tailed) & & .000 & .000 & .635 \\
\hline & $\mathrm{N}$ & 147 & 147 & 147 & 147 \\
\hline \multirow{3}{*}{$\begin{array}{l}\text { NDMSs \& PR } \\
\text { (Resistance Minimizing) }\end{array}$} & Pearson Correlation & .936 & 1 & .918 & .081 \\
\hline & Sig. (2-tailed) & .000 & & .000 & .331 \\
\hline & $\mathrm{N}$ & 147 & 147 & 147 & 147 \\
\hline \multirow{3}{*}{$\begin{array}{l}\text { NDMSs \& PR } \\
\text { (Dissent Management) }\end{array}$} & Pearson Correlation & .874 & .918 & 1 & -.049 \\
\hline & Sig. (2-tailed) & .000 & .000 & & .558 \\
\hline & $\mathrm{N}$ & 147 & 147 & 147 & 147 \\
\hline \multirow[t]{3}{*}{ NDMSs \& AE } & Pearson Correlation & .039 & .081 & -.049 & 1 \\
\hline & Sig. (2-tailed) & .635 & .331 & .558 & \\
\hline & $\mathrm{N}$ & 147 & 147 & 147 & 147 \\
\hline
\end{tabular}

To answer the fourth research question, the elicited responses from half of the respondents $(n=74)$ were converted into three types of answers (i.e. yes, no, undecided) then the data were analyzed in terms of frequency of each answer type (see Table 13) with respect to position (teacher/student). Both students and learners provided revealing data in terms of the necessity of providing a learner-friendly environment where a variety of motivational factors from psychological to cultural and social vantage points are catered for. Some of the interviewees also referred to the concept of identity preservation, which was not precisely the focus of the study but might be addressed in future studies. They believed that one of the outcomes of meeting nonlinear dynamic motivation at individual level (which is the focus of the present study) is that those students with modest backgrounds or from a different race will have an opportunity to introduce/discuss and reinforce their personal nonlinear dynamic motivational factors. The interviewees also described the NDMSs as effective tools to manage AE and PR in L2 learning because they can create motivational individual learners who have identified their nonlinear dynamic motivational factors (by themselves or with their teachers) and have recognized the large range of dynamicity and nonlinearity from one classmate to another.

Table 13

Interview Frequencies

\begin{tabular}{llccc}
\hline \multicolumn{4}{c}{$\begin{array}{c}\text { Interview Frequencies } \\
\text { Count }\end{array}$} \\
\cline { 3 - 4 } & \multicolumn{3}{c}{ Position } & Total \\
\cline { 3 - 5 } & & Student & Teacher & \\
\hline \multirow{3}{*}{ Interview } & Yes & 12 & 56 & $\mathbf{6 8}$ \\
& Undecided & 3 & 0 & $\mathbf{3}$ \\
Total & No & 3 & 0 & $\mathbf{3}$ \\
\hline
\end{tabular}

\section{Discussion}

The AE and the PR, in the learning context, negatively affect the learning process and it is critical to elaborate on this problem. The NDMSs were suggested as the solution to this problem, but the goal was to elicit students' opinions as well as teachers' opinions on their effectiveness to manage or minimize AE and PR. Drawing on psychological reactance theory, the required data were collected from both sides of the oppositional behavior (teachers and students) concerning the effectiveness of the proposed strategies. The quantitative results of 
the study revealed that $85.71 \%$ of the participants held a positive view on the effectiveness of the proposed strategies. The data triangulation of the collected data from the questionnaire and the interview confirmed the effectiveness of the proposed strategies along with a number of suggestions for further studies in the field with the same focus. Individual differences are common and holding double standards is also common among some teachers. Therefore, it is highly critical to take precautionary measures and prevent oppositional behavior via the NDMSs in a learner-friendly environment. As one of the interviewees argued, how could a teacher with double standards fairly evaluate language proficiency in a test-oriented classroom with some students holding opposite standards (different religion, ethnicity, political party, etc.), or how could a demotivating L2 teacher using discriminatory statements, feedback, responses, etc. create an environment free from AE and PR? Given the probability of such discriminatory situations where there is a high chance of stirring psychological reactance and academic entitlement, some questions arise: Is it fair to blame only learner(s) for feeling entitled to achievement/psychological reactance?, Are teachers sufficiently well-informed and well-equipped to prevent academic entitlement/psychological reactance?

The findings of the study are in line with the reported relationship between AE and motivation (Graham, \& Weiner, 1996; Lerner, 1987) and PR and motivation (Jost, Banaji, \& Nosek, 2004). Given the obtained results, it seems imperative to conduct further studies in terms of demotivating L2 teaching environments. Ruling classrooms with an iron fist is an explicit violation of motivational factors and leads to a variety of obstructive factors. Additionally, with regards to similar characteristics of AE and PR with L2 motivation in terms of nonlinearity and dynamicity, further studies are necessary to clarify their connections. Accordingly, it is critical to investigate and determine the potential behind nonlinearity and dynamicity of language learning and language learners (Bahari, 2018; Buehl \& Beck, 2015; Fives \& Gill, 2015; Fives, Lacatena, \& Gerard, 2015) along with learning-related findings of studies on psychological reactance (Chartrand, Dalton, \& Fitzsimons, 2007; Dillard \& Shen, 2005; Eagly, Mladinic, \& Otto, 1994; Kim, Levine, \& Allen, 2013; Quick \& Considine, 2008; Quick \& Stephenson, 2007; Rains, 2013) towards a comprehensive PR-free model of learning.

The misguided theoretical trend in L2 motivation studies is mainly under the influence of L2 self systems introduced by Dörnyei (2009) and the studies that tried to expand it (e.g. Liu \& Thompson, 2018; Thompson, 2017) at the cost of confusing anti-ought-to-self with a form of PR (see Bahari, 2020a). The current theoretical trends fail to incorporate the dynamicity and nonlinearity of L2 motivation, which varies from one learner to another. Some peer-reviewed journals such as System and Modern Language Journal, without conducting rigorous review, publish articles contextualizing or expanding this deficient theoretical system and serve to mix up PR and its forms with anti-ought-to-self for readers. Psychological reactance is a psychological state of mind that might cause a range of oppositional expressions (e.g. incivility, dissent, and resistance). However, anti-oughtto-self is a type of self, which serves to negatively motivate the L2 learner to continue the learning process. Briefly, anti-ought-to-self negatively motivates the learner to do something positive (i.e. learning) while PR negatively motivates the learner not to do something positive (i.e. learning). While the former potentially facilitates learning, the latter practically obstructs learning.

\section{Pedagogical Implications}

The most salient pedagogical implication of the study is about test-oriented classes and their negative effect on managing and minimizing AE and PR. Such classes increase the chances of the emergence of AE and PR in the three forms of incivility, dissent, and resistance along with learner-teacher self-doubt, anxiety, and frustration. Such classes not only provide some teachers with a manipulative tool (i.e. test score manipulation) to threaten or oppress learner autonomy but also help them dodge their responsibility to prepare novel and creative activities compatible with learners' dynamic and nonlinear motivation. Some of the teacher-participants also implicitly confirmed the existence of such reactance-inducing conditions in L2 teaching-learning contexts. Therefore, some pedagogical reformations are needed to address these anti-learner features of test-oriented classes that affect L2 teaching-learning environments. The second implication is that reinforcing nonlinear dynamic motivation has the potential to prevent incivility, minimize resistance, and manage dissent along with catering to the motivational needs of the L2 learner group at the same time. The NDMSs-oriented pedagogy ensures learner-friendly environments where L2 learner motivation is catered to at individual level (Bahari, 2020b). In keeping with the dynamicity and nonlinearity of learner's motivation, the third implication of the study is the need to foster the collaborative meaning-making process through dialogic discourse instead of traditionally established monologic discourse in L2 teaching-learning. This is to integrate the dynamic and nonlinear features 
of L2 motivation at the individual level with that of the group level during interactional synchrony. While the former discourse type permits argumentative virtues, the latter one fosters teacher-centered teaching beliefs.

\section{Conclusion}

Based on participants' beliefs, this study confirms the effectiveness of the NDMSs as a valid tool for minimizing and managing psychological reactance and academic entitlement in L2 learning-teaching contexts. Accordingly, it can safely be concluded that restraining learner's freedom of voice, preferences, and options within a demotivating, undemocratic L2 classroom causes oppositional behaviors, which need to be avoided on the part of the teacher. The study confirms a positive opinion among teachers as well as learners on the applicability of the NDMSs as a minimizing and managing tool for academic entitlement and psychological reactance. The study suggests new pedagogical reforms in terms of teachers' belief systems about teaching practices with a focus on the nonlinearity and dynamicity of motivation, which differs from learner to learner. Given the thin literature apropos of the nonlinearity and dynamicity of L2 motivation, future studies are suggested to retest the applicability and contextualization of the NDMSs in different learning contexts and at different language proficiency levels. The main point of the study is to benefit from the diversity of L2 motivation in learners to create an every-learner-motivated classroom.

\section{References}

Achacoso, M. V. (2002). "What do you mean my grade is not an A?" An investigation of academic entitlement, causal attributions, and self-regulation in college students [Unpublished doctoral dissertation]. The University of Texas at Austin.

Bahari, A. (2018). Nonlinear dynamic motivation-oriented telecollaborative model of language learning via formulaic sequences to foster learner autonomy. The Journal of Teaching English with Technology, 18(3), 6581. http://www.tewtjournal.org

Bahari, A. (2019a). FonF practice model from theory to practice: CALL via focus on form approach and nonlinear dynamic motivation to develop listening and speaking proficiency. Computers \& Education, 130(3), 40-58. http://doi.org/10.1016/j.compedu.2018.11.009

Bahari, A. (2019b). The Impact of applying FonF practice model on developing L2 listening and speaking with a focus on intentional and incidental vocabulary acquisition in CALL context. Revista de Lingüística y Lenguas Aplicadas, 14, 1-15. http://doi.org/10.4995/rlyla.2019.10785

Bahari, A. (2020a). Mainstream theoretical trends and future directions of L2 motivation studies in classroom and CALL contexts. CALL-EJ, 21(1), 1-28.

Bahari, A. (2020b). Computer-Assisted Language Proficiency Assessment Tools and Strategies. Open Learning: The Journal of Open, Distance and e-Learning, 35(2), 34-59. http://doi.org/10.1080/02680513.2020.1726738

Bjorklund, W. L., \& Rehling, D. L. (2009). Student perceptions of classroom incivility. College Teaching, 58(1), 15-18. https://doi.org/10.1080/87567550903252801

de Bot, K., Lowie, W., \& Verspoor, M. (2007). A dynamic systems theory approach to second language acquisition. Bilingualism: Language and Cognition 10(1), 7-21. https://doi.org/10.1017/S1366728906002732

de Bot, K., \& Larsen Freeman, L. (2011). Researching second language development from a dynamic systems theory perspective. In M. H. Verspoor, K. de Bot \& W. Lowie (Eds.), A dynamic approach to second language development: Methods and techniques (pp. 5-24). John Benjamins.

Brehm, J. W. (1966). A theory of psychological reactance. Academic Press.

Brehm, S., \& Brehm, J. W. (1981). Psychological reactance: A theory of freedom and control. Academic Press.

Buehl, M. M., \& Beck, J. S. (2015). The relationship between teachers' beliefs and teachers' practices. In H. Fives \& M. Gregoire Hill (Eds.), International handbook of research on teachers' beliefs (pp. 66-84). Routledge.

Campbell, W. K., Bonacci, A. M., Shelton, J., Exline, J. J., \& Bushman, B. J. (2004). Psychological entitlement: Interpersonal consequences and validation of a self-report measure. Journal of Personality Assessment, 83(1), 29-45. https://doi.org/10.1207/s15327752jpa8301_04

Chartrand, T. L., Dalton, A. N., \& Fitzsimons, G. J. (2007). Nonconscious relationship reactance: When significant others prime opposing goals. Journal of Experimental Social Psychology, 43, 719-726. https://doi.org/10.1016/j. 
jesp.2006.08.003

Chomeya, R. (2010). Quality of Psychology Test between Likert Scale 5 and 6 Points. Journal of Social Sciences, 6(3), 399-403.

Chowning, K., \& Campbell, N. J. (2009). Development and validation of a measure of academic entitlement: Individual differences in students' externalized responsibility and entitled expectations. Journal of Educational Psychology, 101(4), 982-997. https://doi.org/10.1037/a0016351

Ciani, K. D., Summers, J. J., \& Easter, M. A. (2008). Gender differences in academic entitlement among college students. The Journal of Genetic Psychology, 169(4), 332-344. https://doi.org/10.3200/GNTP.169.4.332-344

Clark, C. M., \& Springer, P. J. (2007). Thoughts on incivility: Student and faculty perceptions of uncivil behavior in nursing education. Nursing Education Perspectives, 28(2), 93-97. https://doi.org/10.12691/ajnr-4-3-2.

Cortina, L. M., Magley, V. J., Williams, J. H., \& Langhout, R. D. (2001). Incivility at the workplace: Incidence and impact. Journal of Occupational Health Psychology, 6, 64-80. https://doi.org/10.1037/1076-8998.6.1.64

Csizer, K., \& Luk_acs, G. (2010). The comparative analysis of motivation, attitudes and selves: The case of English and German in Hungary. System, 38(1), 1-13. https://doi.org/10.1016/j.system.2009.12.001

Csizer, K., \& Magid, M. (Eds.). (2014). The impact of self-concept on language learning. Multilingual Matters.

Dillard, J. P., \& Shen, L. (2005). On the nature of reactance and its role in persuasive health communication. Communication Monographs, 72, 144-168. http://doi.org/10.1080/03637750500111815

Dörnyei, Z. (2009). The L2 motivational self-system. In Z. Dörnyei \& E. Ushioda (Eds.), Motivation, language identity and the L2 self (pp. 9-42). Multilingual Matters. http://doi.org/10.14746/ssllt.2018.8.4.2

Dörnyei, Z. (2010). The relationship between language aptitude and language learning motivation: Individual differences from a dynamic systems perspective. In E.Macaro (Ed.), Continuum companion to second language acquisition (pp. 247-267). Continuum. http://doi.org/10.5040/9781474212397.ch-009

Dörnyei, Z., \& Chan, L. (2013). Motivation and vision: An analysis of future L2 self-images, sensory styles, and imagery capacity across two target languages. Language Learning, 63, 437-462. http://doi.org/10.1111/ lang.12005

Dörnyei, Z., Henry, A., \& Muir, C. (2016). Motivational currents in language learning: Frameworks for focused interventions. Routledge.

Dörnyei, Z., Ibrahim, Z., \& Muir, C. (2015). Directed Motivational Currents: Regulating complex dynamic systems through motivational surges. In Z. Dörnyei, Z., MacIntyre, P., \& Henry, A. (Eds.), Motivational dynamics in language learning. Multilingual Matters.

Dörnyei, Z., \& Ryan, S. (2015). The psychology of the language learner revisited. Routledge.

Eagly, A. H., Mladinic, A., \& Otto, S. (1994). Cognitive and affective bases of attitudes toward social groups and social policies. Journal of Experimental Social Psychology, 30, 113-137. http://doi.org/10.1006/jesp.1994.1006

Feldmann, L. J. (2001). Classroom civility is another of our instructor responsibilities. College Teaching, 49, 137140. https://doi.org/10.1080/87567555.2001.10844595

Fives, H., \& Gill, M. G. (Eds.). (2015). International handbook of research on teachers' beliefs. Routledge.

Fives, H., Lacatena, N., \& Gerard, L. (2015). Teachers' beliefs about teaching (and learning). In H. Fives \& M. G. Gill (Eds.), International handbook of research on teachers' beliefs (pp. 249-265). Routledge.

Foster, J. D., Campbell, W. K., \& Twenge, J. M. (2003). Individual differences in narcissism: Inflated self views across the lifespan and around the world. Journal of Research in Personality, 37(6), 469-486. https://doi. org/10.1016/S0092-6566(03)00026-6

Fusella, P. V. (2013). Dynamic systems theory in cognitive science: Major elements, applications, and debates surrounding a revolutionary meta-theory. Dynamic Psychology, 1, 258-307. http://dynapsyc.org/2013/ Fusella.pdf

Graham, S., \& Weiner, B. (1996). Theories and principles of motivation. In D. C. Berliner \& R. C. Calfee (Eds.), Handbook of educational psychology (pp. 63-84). Macmillan.

Greenberger, E., Lessard, J., Chen, C., \& Farruggia, S. P. (2008). Self- entitled college students: Contributions of personality, parenting, and motivational factors. Journal of Youth and Adolescence, 37(10), 1193-1204. https://doi.org/10.1007/s10964-008-9284-9

Griffiths, C. (2013). The strategy factor in successful language learning. Multilingual Matters.

Henry, A., Davydenko, S., \& Dörnyei, Z. (2015). The anatomy of directed motivational currents: Exploring intense and enduring periods of L2 motivation. Modern Language Journal, 99, 329- 345. https://doi.org/10.1111/ modl.12214

Hiver, P. (2015). Attractor states. In Z. Dörnyei, P. MacIntyre, \& A. Henry (Eds.), Motivational dynamics in language learning (pp. 20-28). Multilingual Matters. https://doi.org/10.13140/RG.2.1.2501.8722

Hiver, P., \& Al-Hoorie, A. H. (2016). A dynamic ensemble for second language research: Putting Complexity 
Theory into practice. Modern Language Journal, 100, 741-756. https://doi.org/10.1111/modl.12347

Hoover, E. (2007). Here's looking at you, kid: Study says many students are narcissists. Chronicle of Higher Education, 53(27). https://eric.ed.gov/?id=EJ757228

Jiang, Y., \& Dewaele, J. M. (2015). What lies bubbling beneath the surface? A longitudinal perspective on fluctuations of ideal and Ought-to L2 self among Chinese learners of English. International Review of Applied Linguistics in Language Teaching, 53, 331-354. https://doi.org/10.1515/iral-2015-0015

Jost, J. T., Banaji, M. R., \& Nosek, B. A. (2004). A decade of system justification theory: Accumulated evidence of conscious and unconscious bolstering of the status quo. Political Psychology, 25, 881-919. https://doi. org/10.1111/j.1467-9221.2004.00402.x

Kikuchi, K. (2015). Demotivation in second language acquisition. Multilingual Matters.

Kim, K. J. (2009). Demotivating factors in secondary English education. English Teaching, 64(4), 249-267. https:// doi.org/10.15858/engtea.64.4.200912.249

Kim, S., Levine, T., \& Allen, M. (2013). Comparing separate process and intertwined models for reactance. Communication Studies, 64, 273-295. http://doi.org/10.1080/10510974.2012.755639

Lamb, M. (2012). A self-system perspective on young adolescents' motivation to learn English in urban and rural settings. Language Learning, 62(4), 997-1023. https://doi.org/10.1111/j.1467-9922.2012.00719.x

Larsen-Freeman, D. (2015a). Ten 'lessons' from Complex Dynamic Systems Theory: What is on offer. In Z. Dörnyei, P.D. MacIntyre \& A. Henry (Eds.), Motivational dynamics in language learning (pp.11-19). Multilingual Matters. https://doi.org/10.21832/9781783092574-004

Larsen-Freeman, D. (2015b). Complexity theory. In B. VanPatten \& J. Williams (Eds.), Theories in second language acquisition: An introduction (2nd ed., pp. 227-244). Routledge

Larsen-Freeman, D., \& Cameron, L. (2008). Complex systems and applied linguistics. Oxford University Press.

Laurin, K., Kay, A. C., Proudfoot, D., \& Fitzsimons, G, J. (2013). Response to restrictive policies: Reconciling system justification and psychological reactance. Organizational Behavior and Human Decision Processes, 122, 152-162. https://doi.org/10.1016/j.obhdp.2013.06.004

Lerner, M. J. (1987). Integrating societal and psychological rules of entitlement: The basic task of each social actor and fundamental problem for the social sciences. Social Justice Research, 1, 107-125. https://doi. org/10.1007/BF01049386

Liu, Y., \& Thompson, A.S. (2018). Language learning motivation in China: An exploration of the L2MSS and psychological reactance. System, 72, 37-48. https://doi.org/10.1016/j.system.2017.09.025

Lombardi, J. V. (2007). The academic success entitlement. Inside Higher Education. http://www.insidehighered. com/

Lyubomirsky, S., \& Layous, K. (2013). How do simple positive activities increase well-being? Current Directions in Psychological Science, 22, 57-62. http://doi.org/10.1177/0963721412469809

MacIntyre, P. D., \& Legatto, J. J. (2011). A dynamic system approach to willingness to communicate: Developing and idiodynamic method to capture rapidly changing affect. Applied Linguistics, 32(2), 149-171. https://doi. org/10.1093/applin/amq037

Major, B. (1994). From social inequality to personal entitlement: The role of social comparisons, legitimacy appraisals, and group memberships. Advances in Experimental Social Psychology, 26, 293-355. https://doi. org/10.1016/S0065-2601(08)60156-2

Miron, A. M., \& Brehm, J. W. (2006). Reactance theory-40 years later. Social Psychology, 37, 9-18. https://doi. org/10.1024/0044-3514.37.1.9

Morrow, W. (1994). Entitlement and achievement in education. Studies in Philosophy and Education, 13(1), 33-47. https://doi.org/10.1007/BF01074084

Moskovsky, C., Racheva, S., Assulaimani, T., \& Harkins, J. (2016). The L2 Motivational Self System and L2 Achievement: A study of Saudi EFL learners. The Modern Language Journal, 100(3), 641-654. https://doi. org/10.1111/modl.12340

Oxford, R. (2017). Teaching and researching language learning strategies: Self-regulation in context (2nd ed.). Routledge.

Quick, B. L., \& Considine, J. R. (2008). Examining the use of forceful language when designing exercise persuasive messages for adults: A test of conceptualizing reactance arousal as a two-step process. Health Communication, 23, 483-491. http://doi.org/10.1080/10410230802342150

Quick, B. L., \& Stephenson, M. T. (2007). Further evidence that psychological reactance can be modeled as a combination of anger and negative cognitions. Communication Research, 34, 255-276. http://doi. org/10.1177/0093650207300427

Quoidbach, J., Mikolajczak, M., \& Gross, J. J. (2015). Positive interventions: An emotion regulation perspective. 
Psychological Bulletin, 141, 655-693. http://doi.org/10.1037/a0038648

Rains, S.A.(2013). The nature of psychological reactance revisited:A meta-analytic review.Human Communication Research, 39, 47-73. http://doi.org/10.1111/j.1468-2958.2012.01443.x

Rusk, R. D., \& Waters, L. (2015). A psycho-social system approach to well-being: Empirically deriving the five domains of positive functioning. The Journal of Positive Psychology, 10, 141-152. http://doi.org/10.1080/174 39760.2014.920409

Schunk, D. H., \& Zimmerman, B. J. (2012). Motivation and self-regulated learning: Theory, research, and applications. Routledge.

Serafini, E. J. (2017). Exploring the dynamic long-term interaction between cognitive and psychosocial resources in adult second language development at varying proficiency. The Modern Language Journal, 101(2), 369-390. http://doi.org/10.1111/modl.12400

Sheldon, K., Boehm, J., \& Lyubomirsky, S. (2013). Variety is the spice of happiness: The hedonic adaptation prevention (HAP) model. In S. A. David, I. Boniwell, \& A. C. Ayers (Eds.), Oxford handbook of happiness (pp. 901-914). Oxford University Press. http://doi.org/10.1093/oxfordhb/9780199557257.013.0067

Tashakkori, A. \& Teddlie, C. (2003). Handbook of mixed methods in social \& behavioral research. Sage.

Thompson, A. S., (2017). Don't tell me what to do! The anti-ought-to self and language learning motivation. System, 67, 38-49. http://doi.org/10.1016/j.system.2017.04.004

Thompson, A. S., \& Erdil-Moody, Z. (2016). Operationalizing multilingualism: Language learning motivation in Turkey. International Journal of Bilingual Education and Bilingualism, 19(3), 314-331. http://dx.doi.org/10.10 80/13670050.2014.985631

Twenge, J. M. (2006). Generation me: Why today's young Americans are more confident, assertive, entitled - And more miserable than ever before. Free Press

Ushioda, E., \& Dörnyei, Z. (2017). Beyond Global English: Motivation to learn languages in a multicultural world: Introduction to the special issue. The Modern Language Journal, 101(3), 451-454. https://doi.org/10.1111/ modl. 12407

You, C., \& Chan, L. (2015). The dynamics of L2 imagery in future motivational self-guides. In Z. Dörnyei, P. D. MacIntyre \& A. Henry (Eds.), Motivational dynamics in language learning (pp. 405-430). Multilingual Matters. https://doi.org/10.1057/9781137457134_3

You, C., Dörnyei, Z. \& Csiz'er, K. (2016). Motivation, vision, and gender: A survey of learners of English in China, language learning, 66(1), 94-123. http://doi.org/10.1111/lang.12140

Waninge, F., Dörnyei, Z., \& de Bot, K. (2014). Motivational dynamics in language learning: Change, stability, and context. Modern Language Journal, 98, 704-723. https://doi.org/10.1111/modl.12118

Wigfield, A., \& Guthrie, J. T. (1995). Dimensions of children's motivations for reading: An initial study (Research Rep. No. 34). National Reading Research Center.

Wigfield, A., \& Guthrie, J.T. (1997). Relations of children's motivation for reading to the amount and breadth of their reading. Journal of Educational Psychology, 89(3), 420-432. https://doi.org/10.1037/0022-0663.89.3.420 


\section{Appendix A}

This questionnaire asks L2 learner/teacher to rate their opinions concerning the effectiveness of the NDMSs to manage PR at three levels of incivility prevention, dissent management, and resistance minimizing

\section{NDMSs - PR Questionnaire}

\begin{tabular}{|c|c|c|c|c|c|c|c|c|}
\hline $\begin{array}{l}\text { Psychological } \\
\text { Reactance } \\
\text { Levels }\end{array}$ & $\begin{array}{l}\text { Focus of } \\
\text { statements }\end{array}$ & Statements & 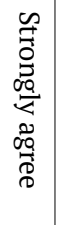 & 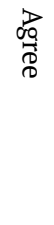 & 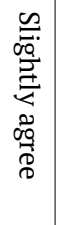 & 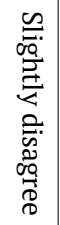 & 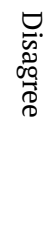 & 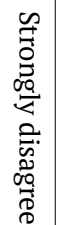 \\
\hline \multirow[t]{15}{*}{$\begin{array}{l}\text { Incivility } \\
\text { Prevention }\end{array}$} & Anxiety & $\begin{array}{l}\text { I think applying NDMSs along with learner-centered strategies can } \\
\text { prevent learner incivility and reduce learner-teacher anxiety }\end{array}$ & & & & & & \\
\hline & Anxiety & $\begin{array}{l}\text { I believe that NDMSs have the potential to reduce the negative } \\
\text { impact of test-oriented classes which act against learner } \\
\text { motivation and increase learner anxiety and learner incivility }\end{array}$ & & & & & & \\
\hline & Anxiety & $\begin{array}{l}\text { I believe that NDMSs have the potential to minimize reactance- } \\
\text { inducing statements used by some teachers which act against } \\
\text { learner motivation and increase anxiety and incivility }\end{array}$ & & & & & & \\
\hline & Anxiety & $\begin{array}{l}\text { I believe that NDMSs have the potential to reduce reactance- } \\
\text { inducing statements by some motivating strategies to reduce } \\
\text { learner anxiety and incivility }\end{array}$ & & & & & & \\
\hline & Anxiety & $\begin{array}{l}\text { I believe that NDMSs have the potential to replace test-score } \\
\text { manipulation with a learn-friendly context which minimizes } \\
\text { learner anxiety and incivility }\end{array}$ & & & & & & \\
\hline & Frustration & $\begin{array}{l}\text { I believe that NDMSs have the potential to improve learners' low } \\
\text { achievement which has demotivating effects and causes frustration } \\
\text { and incivility among learners }\end{array}$ & & & & & & \\
\hline & Frustration & $\begin{array}{l}\text { I think lack of novel activities in L2 teaching causes frustration } \\
\text { among learners but I believe that NDMSs have the potential to } \\
\text { minimize frustration }\end{array}$ & & & & & & \\
\hline & Frustration & $\begin{array}{l}\text { I believe that restrictive classes act against NDMSs and increase } \\
\text { learner frustration and learner incivility }\end{array}$ & & & & & & \\
\hline & Frustration & $\begin{array}{l}\text { I think test-score manipulation by teachers act against NDMSs and } \\
\text { causes frustration and incivility }\end{array}$ & & & & & & \\
\hline & Frustration & $\begin{array}{l}\text { I think meeting learners' motivational factors in classroom/online } \\
\text { L2 teaching can reduce frustration and incivility }\end{array}$ & & & & & & \\
\hline & self-doubt & $\begin{array}{l}\text { I think lack of novel activities in L2 teaching causes self-doubt } \\
\text { among teachers which leads to incivility }\end{array}$ & & & & & & \\
\hline & self-doubt & $\begin{array}{l}\text { I believe that restrictive classes act against NDMSs and increase } \\
\text { learner self-doubt and learner incivility }\end{array}$ & & & & & & \\
\hline & self-doubt & $\begin{array}{l}\text { I think test-score manipulation by teachers act against NDMSs and } \\
\text { causes self-doubt and incivility }\end{array}$ & & & & & & \\
\hline & self-doubt & $\begin{array}{l}\text { I think lack of objective criteria and subjective assessment } \\
\text { increases self-doubt among learners and might lead to incivility } \\
\text { over a low grade }\end{array}$ & & & & & & \\
\hline & self-doubt & $\begin{array}{l}\text { I think meeting learners' motivational factors in classroom/online } \\
\text { L2 teaching can reduce self-doubt and incivility }\end{array}$ & & & & & & \\
\hline
\end{tabular}




\begin{tabular}{|c|c|c|c|c|c|c|c|c|}
\hline $\begin{array}{l}\text { Psychological } \\
\text { Reactance } \\
\text { Levels }\end{array}$ & $\begin{array}{l}\text { Focus of } \\
\text { statements }\end{array}$ & Statements & 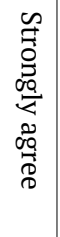 & 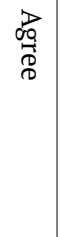 & 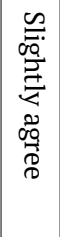 & 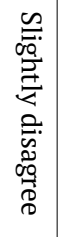 & 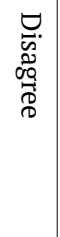 & 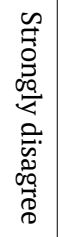 \\
\hline \multirow[t]{15}{*}{$\begin{array}{l}\text { Dissent } \\
\text { Management }\end{array}$} & Anxiety & $\begin{array}{l}\text { I believe that catering for learners' dynamic motivational factors } \\
\text { via NDMSs can reduce the level of dissent and create a friendly } \\
\text { environment with less anxiety and self-doubt }\end{array}$ & & & & & & \\
\hline & Anxiety & $\begin{array}{l}\text { I believe that restrictive classes act against NDMSs and increase } \\
\text { learner anxiety and learner dissent }\end{array}$ & & & & & & \\
\hline & Anxiety & $\begin{array}{l}\text { I think test-score manipulation by teachers act against NDMSs and } \\
\text { causes anxiety and dissent among learners }\end{array}$ & & & & & & \\
\hline & Anxiety & $\begin{array}{l}\text { I think lack of objective criteria and subjective assessment } \\
\text { increases anxiety among learners and might lead to dissentive } \\
\text { behavior over a low grade }\end{array}$ & & & & & & \\
\hline & Anxiety & $\begin{array}{l}\text { I think meeting learners' motivational factors in classroom/online } \\
\text { L2 teaching can reduce anxiety and dissent }\end{array}$ & & & & & & \\
\hline & Frustration & $\begin{array}{l}\text { I think low achievement has demotivating effects and causes } \\
\text { frustration and dissent among learners therefore improving } \\
\text { learner achievement can facilitate dissent management }\end{array}$ & & & & & & \\
\hline & Frustration & $\begin{array}{l}\text { I think lack of novel activities in L2 teaching causes frustration } \\
\text { among learners which leads to learner dissent }\end{array}$ & & & & & & \\
\hline & Frustration & $\begin{array}{l}\text { I believe that threatening activities act against NDMSs and increase } \\
\text { learner frustration and learner dissent }\end{array}$ & & & & & & \\
\hline & Frustration & $\begin{array}{l}\text { I think test-score manipulation by teachers act against NDMSs and } \\
\text { causes frustration and dissent among learners }\end{array}$ & & & & & & \\
\hline & Frustration & $\begin{array}{l}\text { I think lack of objective criteria or ignoring them in subjective } \\
\text { assessment of assignments has demotivating effects and increases } \\
\text { frustration among learners which might lead to dissentive } \\
\text { behaviors over a low grade }\end{array}$ & & & & & & \\
\hline & self-doubt & $\begin{array}{l}\text { I believe that catering for learners' dynamic motivational factors } \\
\text { via NDMSs can reduce the level of dissent and create a friendly } \\
\text { environment with less anxiety and self-doubt }\end{array}$ & & & & & & \\
\hline & self-doubt & $\begin{array}{l}\text { I think lack of novel activities in L2 teaching has demotivating } \\
\text { effects and causes self-doubt among teachers which leads to } \\
\text { teacher dissent }\end{array}$ & & & & & & \\
\hline & self-doubt & $\begin{array}{l}\text { I believe that test-oriented classes act against NDMSs and increase } \\
\text { learner self-doubt and learner dissent }\end{array}$ & & & & & & \\
\hline & self-doubt & $\begin{array}{l}\text { I think test-score manipulation by teachers act against NDMSs and } \\
\text { causes self-doubt and dissent among learners }\end{array}$ & & & & & & \\
\hline & self-doubt & $\begin{array}{l}\text { I think lack of objective criteria or ignoring them in subjective } \\
\text { assessment of assignments has demotivating effects and increases } \\
\text { self-doubt among learners which might lead to dissentive } \\
\text { behaviors over a low grade }\end{array}$ & & & & & & \\
\hline
\end{tabular}




\begin{tabular}{|c|c|c|c|c|c|c|c|c|}
\hline $\begin{array}{l}\text { Psychological } \\
\text { Reactance } \\
\text { Levels }\end{array}$ & $\begin{array}{l}\text { Focus of } \\
\text { statements }\end{array}$ & Statements & 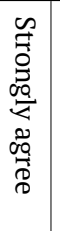 & 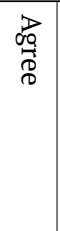 & 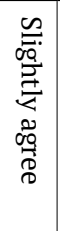 & 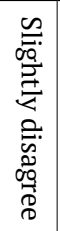 & 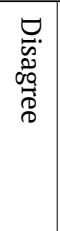 & 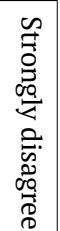 \\
\hline \multirow[t]{14}{*}{$\begin{array}{l}\text { Resistance } \\
\text { Minimizing }\end{array}$} & Anxiety & $\begin{array}{l}\text { I believe that restrictive classes act against NDMSs and increase } \\
\text { learner anxiety and learner resistance }\end{array}$ & & & & & & \\
\hline & Anxiety & $\begin{array}{l}\text { I think test-score manipulation by teachers act against NDMSs and } \\
\text { causes anxiety and resistance }\end{array}$ & & & & & & \\
\hline & Anxiety & $\begin{array}{l}\text { I think lack of objective criteria and subjective assessment has } \\
\text { demotivating effects and increases anxiety among learners which } \\
\text { might lead to resistance over a low grade }\end{array}$ & & & & & & \\
\hline & Anxiety & $\begin{array}{l}\text { I think lack of objective criteria or ignoring them in subjective } \\
\text { assessment of assignments has demotivating effects and increases } \\
\text { anxiety among learners which might lead to resistance over a low } \\
\text { grade }\end{array}$ & & & & & & \\
\hline & Frustration & $\begin{array}{l}\text { I feel less resistance and frustration when a controversial subject is } \\
\text { delivered unbiasedly }\end{array}$ & & & & & & \\
\hline & Frustration & $\begin{array}{l}\text { I think low achievement causes frustration and resistance among } \\
\text { learners therefore improving learner achievement can minimize } \\
\text { learner frustration and resistance }\end{array}$ & & & & & & \\
\hline & Frustration & $\begin{array}{l}\text { I think threatening activities in L2 teaching has demotivating } \\
\text { effects and causes frustration among learners which leads to } \\
\text { learner resistance }\end{array}$ & & & & & & \\
\hline & Frustration & $\begin{array}{l}\text { I believe that test-oriented classes increase learner frustration and } \\
\text { learner resistance }\end{array}$ & & & & & & \\
\hline & Frustration & $\begin{array}{l}\text { I think test-score manipulation by teachers causes frustration and } \\
\text { resistance among learners }\end{array}$ & & & & & & \\
\hline & self-doubt & $\begin{array}{l}\text { I think lack of objective criteria and subjective assessment increases } \\
\text { self-doubt among learners which might lead to resistance over a } \\
\text { low grade }\end{array}$ & & & & & & \\
\hline & self-doubt & $\begin{array}{l}\text { I think test-score manipulation by teachers has demotivating } \\
\text { effects and causes self-doubt and resistance among learners }\end{array}$ & & & & & & \\
\hline & self-doubt & $\begin{array}{l}\text { I believe that restrictive classes increase learner self-doubt and } \\
\text { learner resistance }\end{array}$ & & & & & & \\
\hline & self-doubt & $\begin{array}{l}\text { I think lack of novel activities in L2 teaching causes self-doubt } \\
\text { among teachers which leads to learner resistance }\end{array}$ & & & & & & \\
\hline & self-doubt & $\begin{array}{l}\text { I think threatening activities in L2 teaching has demotivating } \\
\text { effects and causes self-doubt among teachers which leads to } \\
\text { teacher resistance }\end{array}$ & & & & & & \\
\hline
\end{tabular}




\section{Appendix B}

\section{NDMSs - AE Questionnaire}

This questionnaire asks L2 learners/teachers to rate their opinions concerning the effectiveness of NDMSs to manage L2 academic entitlement

\begin{tabular}{|c|c|c|c|c|c|c|c|}
\hline No. & Statement & 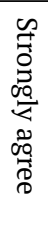 & 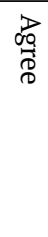 & 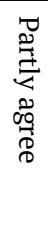 & 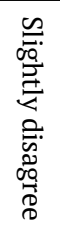 & 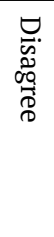 & 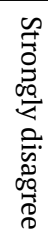 \\
\hline 1 & $\begin{array}{l}\text { There is no place for dictatorial teacher in a democratic learner-friendly L2 } \\
\text { teaching-learning context }\end{array}$ & & & & & & \\
\hline 2 & $\begin{array}{l}\text { Ruling L2 teaching-learning contexts with an iron fist encourages academic } \\
\text { entitlement }\end{array}$ & & & & & & \\
\hline 3 & L2 learners are customers and teachers are responsible for customer services & & & & & & \\
\hline 4 & L2 teachers should adopt NDMSs to improve learners' low self-esteem & & & & & & \\
\hline 5 & $\begin{array}{l}\text { Threatening policies are adopted by L2 teachers as pretexts to hide their lack } \\
\text { of activity on providing novel and motivating materials to the class which meet } \\
\text { nonlinear dynamic motivation of the learner group }\end{array}$ & & & & & & \\
\hline 6 & L2 teachers should adopt NDMSs to improve learners' low achievement & & & & & & \\
\hline 7 & Ruling class by double standards causes demotivation and academic entitlement & & & & & & \\
\hline 8 & $\begin{array}{l}\text { L2 teacher should stop emphasizing on a single shortcoming and ignoring } \\
\text { learner's motivational factors as a penalty for that single shortcoming in a } \\
\text { vindictive manner }\end{array}$ & & & & & & \\
\hline 9 & $\begin{array}{l}\text { Academic entitlement is an excuse to blame students who demand their violated } \\
\text { right from a domineering teacher }\end{array}$ & & & & & & \\
\hline 10 & $\begin{array}{l}\text { Academic entitlement is an excuse to blame students who demand their violated } \\
\text { right from a domineering educational system }\end{array}$ & & & & & & \\
\hline 12 & $\begin{array}{l}\text { Academic entitlement is an excuse to blame students who demand their violated } \\
\text { right from a domineering test-oriented class }\end{array}$ & & & & & & \\
\hline 13 & $\begin{array}{l}\text { Teachers blame learners for being entitled as a way of dodging their } \\
\text { responsibilities }\end{array}$ & & & & & & \\
\hline 14 & Ignoring learners' various test-taking styles lead to academic entitlement & & & & & & \\
\hline 15 & L2 teachers' inflexibility in terms of assignments lead to academic entitlement & & & & & & \\
\hline 16 & L2 teachers' monologic teaching approach leads to academic entitlement & & & & & & \\
\hline
\end{tabular}




\section{Appendix C}

\section{NDMSs-AE and PR Self-Interview}

\begin{tabular}{|c|c|c|c|}
\hline Strategy & Theme & Prompt & Coding responses \\
\hline $\begin{array}{l}\text { Psychological } \\
\text { Strategies }\end{array}$ & $\begin{array}{l}\text { Explaining the effectiveness } \\
\text { of psychological strategies on } \\
\text { psychological reactance and } \\
\text { academic entitlement self- } \\
\text { management }\end{array}$ & $\begin{array}{l}\text { Are psychological strategies influential } \\
\text { in managing psychological reactance and } \\
\text { academic entitlement? }\end{array}$ & $\begin{array}{l}\text { Elicited responses are } \\
\text { interpreted and coded as } \\
1=\text { Yes } \\
2=\text { Undecided } \\
3=\text { No }\end{array}$ \\
\hline \multirow[t]{3}{*}{$\begin{array}{l}\text { Cultural } \\
\text { Strategies }\end{array}$} & \multirow[t]{3}{*}{$\begin{array}{l}\text { Explaining the effectiveness } \\
\text { of cultural strategies on } \\
\text { psychological reactance and } \\
\text { academic entitlement self- } \\
\text { management }\end{array}$} & $\begin{array}{l}\text { * Are cultural strategies influential to manage } \\
\text { psychological reactance and academic } \\
\text { entitlement in L2 teaching -learning contexts? }\end{array}$ & $\begin{array}{l}\text { Elicited responses are } \\
\text { interpreted and coded as } \\
1=\text { Yes } \\
2=\text { Undecided } \\
3=\text { No }\end{array}$ \\
\hline & & $\begin{array}{l}\text { *Are psychological reactance and academic } \\
\text { entitlement important obstructive factors } \\
\text { in L2 teaching-learning based on your own } \\
\text { experiences? }\end{array}$ & $\begin{array}{l}\text { Elicited responses are } \\
\text { interpreted and coded as } \\
1=\text { Yes } \\
2=\text { Undecided } \\
3=\text { No }\end{array}$ \\
\hline & & $\begin{array}{l}\text { * Are you under the effectiveness of } \\
\text { psychological reactance and academic } \\
\text { entitlement in learning-teaching English? }\end{array}$ & $\begin{array}{l}\text { Elicited responses are } \\
\text { interpreted and coded as } \\
1=\text { Yes } \\
2=\text { Undecided } \\
3=\text { No }\end{array}$ \\
\hline \multirow[t]{2}{*}{$\begin{array}{l}\text { Social } \\
\text { Strategies }\end{array}$} & \multirow[t]{2}{*}{$\begin{array}{l}\text { Explaining the effectiveness } \\
\text { social strategies on } \\
\text { psychological reactance and } \\
\text { academic entitlement self- } \\
\text { management }\end{array}$} & $\begin{array}{l}\text { * Are social strategies in L2 teaching -learning } \\
\text { contexts influential? }\end{array}$ & $\begin{array}{l}\text { Elicited responses are } \\
\text { interpreted and coded as } \\
1=\text { Yes } \\
2=\text { Undecided } \\
3=\text { No }\end{array}$ \\
\hline & & $\begin{array}{l}\text { *Are social strategies in managing psychological } \\
\text { reactance and academic entitlement } \\
\text { influential? }\end{array}$ & $\begin{array}{l}\text { Elicited responses are } \\
\text { interpreted and coded as } \\
1=\text { Yes } \\
2=\text { Undecided } \\
3=\text { No }\end{array}$ \\
\hline \multirow[t]{4}{*}{$\begin{array}{l}\text { Psycho-socio- } \\
\text { cultural } \\
\text { Strategies }\end{array}$} & \multirow[t]{4}{*}{$\begin{array}{l}\text { Multiple strategies to manage } \\
\text { psychological reactance and } \\
\text { academic entitlement }\end{array}$} & $\begin{array}{l}\text { *Do you think learner-centered strategies } \\
\text { along with psycho-socio-cultural strategies } \\
\text { can facilitate psychological reactance and } \\
\text { academic entitlement self-management? How? }\end{array}$ & $\begin{array}{l}\text { Elicited responses are } \\
\text { interpreted and coded as } \\
\text { 1= Yes } \\
2=\text { Undecided } \\
3=\text { No }\end{array}$ \\
\hline & & $\begin{array}{l}\text { *Do you think that psycho-socio-cultural can } \\
\text { facilitate preventing incivility, minimizing } \\
\text { resistance, and managing dissent in L2 } \\
\text { teaching-learning? }\end{array}$ & $\begin{array}{l}\text { Elicited responses are } \\
\text { interpreted and coded as } \\
1=\text { Yes } \\
2=\text { Undecided } \\
3=\text { No }\end{array}$ \\
\hline & & $\begin{array}{l}\text { "Do you think that psycho-socio-cultural have } \\
\text { the potential to minimize the negative impact } \\
\text { of obstructive factors? }\end{array}$ & $\begin{array}{l}\text { Elicited responses are } \\
\text { interpreted and coded as } \\
1=\text { Yes } \\
2=\text { Undecided } \\
3=\text { No }\end{array}$ \\
\hline & & $\begin{array}{l}\text { "Do you think that managing obstructive } \\
\text { factors by psycho-socio-cultural strategies can } \\
\text { develop L2 teaching-learning? }\end{array}$ & $\begin{array}{l}\text { Elicited responses are } \\
\text { interpreted and coded as } \\
1=\text { Yes } \\
2=\text { Undecided } \\
3=\text { No }\end{array}$ \\
\hline Part 5 & \multicolumn{3}{|c|}{ Finally Thank you for your time. Do you have any questions that you would like to ask? } \\
\hline
\end{tabular}

